ROCZNIKI HISTORYCZNE

Rocznik LXXXIII - 2017

\author{
ANDRZEJ KAMIEŃSKI (Instytut Historii PAN, Poznań)
}

\title{
Zakon Krzyżacki wobec koronacji elektora brandenburskiego Fryderyka III na króla w Prusach
}

\begin{abstract}
Zarys treści: Protest Zakonu Krzyżackiego wobec koronacji elektora brandenburskiego Fryderyka III na króla w Prusach w 1701 r. przebił się na forum ogólnoniemieckie i europejskie. O jego niepowodzeniu zadecydowała ówczesna sytuacja międzynarodowa. Narastający konflikt habsbursko-burboński o sukcesję hiszpańską zmusił cesarza Leopolda I do opowiedzenia się po stronie Hohenzollerna.
\end{abstract}

Content outline: The protest of the Teutonic Order against the coronation of Frederic III, Elector of Brandenburg, as the king in Prussia in 1701, reached the German and European forum. Its failure was caused by the international situation. The growing conflict between Habsburgs and Bourbons regarding the Spanish succession forced Emperor Leopold I to take Hohenzollern's side.

Słowa kluczowe: Zakon Krzyżacki, Hohenzollernowie, Królestwo w Prusach, Cesarstwo

Keywords: Teutonic Order, Hohenzollerns, Kingdom in Prussia, Empire

Kwestia reakcji Zakonu Krzyżackiego na wyniesienie władztwa Hohenzollernów brandenburskich do rangi królestwa doczekała się już opracowania. Pokłosiem obchodzonej w Niemczech okrągłej rocznicy koronacji królewieckiej z 1701 r. były nie tylko publikacje naukowe omawiające to wydarzenie od strony dworu berlińskiego i awansu państwa brandenbursko-pruskiego. Ukazały się bowiem także wartościowe artykuły dotyczące samego protestu krzyżackiego ${ }^{1}$. Ich autorzy skupili się jednak na działaniach krzyżackich podejmowanych przeciwko Hohenzollernowi w obrębie Rzeszy Niemieckiej, rezygnując z przedstawienia ich na szerszym tle międzynarodowym. Kontekst międzynarodowy protestu krzyżackiego, który zbiegł się w czasie z dojrzewającym burbońsko-habsburskim konfliktem zbrojnym o sukcesję hiszpańską, dostrzegł już w XIX w. historyk francuski Albert Waddington, ale i on nie poświęcił mu zbyt wiele uwagi. W jego pracy znajdujemy nieliczne wzmianki świadczące o wspólnocie interesów, która połączyła wówczas władze zakonne z innymi wrogami

1 D. J. W e is s, Der Protest des Deutschen Ordens gegen die preußische Königskrönung 1701, w: Die preußische Rangerhöhung und Königskrönung 1701 in deutscher und europäischer Sicht, Frankfurt am Main 2002, s. 63-82; F. Vo g e 1, Die preußische Königskrönung und der Deutsche Orden (1695-1701), w: Die landesgeschichtliche Bedeutung der Königskrönung von 1701, Marburg 2004 (Tagungsberichte der Historischen Kommission für Ost- und Westpreussische Landesforschung 18), s. 149-182. 
Hohenzollernów ${ }^{2}$. A był to przecież jeden z czynników sprawczych przedostania się skarg krzyżackich na forum ogólnoniemieckie i europejskie, a co za tym idzie - chwilowego zaistnienia Zakonu Krzyżackiego, po raz ostatni w historii, w roli gracza politycznego. Epizod z 1701 r. zasługuje zatem na ponowne przyjrzenie się mu z innej niż dotąd perspektywy. Celem niniejszego artykułu jest nie tylko przypomnienie argumentacji prawnej Zakonu i poszerzenie jej przedstawienia o kilka nieznanych dotąd szczegółów, ale również znalezienie odpowiedzi na pytanie, co sprawiło, że akcja krzyżacka, która uzyskała początkowo tak duży rozgłos, straciła szybko na znaczeniu.

Okolicznością sprzyjającą wystąpieniu krzyżackiemu z 1701 r. było z pewnością objęcie godności wielkiego mistrza ocalałych resztek Zakonu w 1694 r. przez biskupa wrocławskiego Franciszka Ludwika von Pfalz-Neuburg. Wbrew ucierającemu się już w XVII w. zwyczajowi nie był on Habsburgiem, lecz Wittelsbachem, co pozwalało mu na zachowanie wąskiego marginesu swobody. Posiadał jednak sojuszników także na dworze wiedeńskim. Starsza siostra Wittelsbacha, Eleonora Magdalena, była bowiem od $1676 \mathrm{r}$. żoną cesarza Leopolda $\mathrm{I}^{3}$. Koneksje wielkiego mistrza z Hofburgiem okazały się pożyteczne dla Zakonu, gdy ten wystąpił w obronie swych historycznych praw do Prus, protestując przeciwko używaniu przez Hohenzollernów na mocy układu brandenbursko-austriackiego z 20 XII 1694 r. tytułu ,książąt w Prusach" (Herzog in Preußen)4. W dniu 18 X 1695 r. Franciszek Ludwik zwrócił się bezpośrednio do swego cesarskiego szwagra w kwestii nowej tytulatury margrabiów brandenburskich, wyrażając nadzieję, że najznaczniejszy katolicki władca Europy będzie stał na straży wszystkich dekretów, deklaracji i przywilejów wystawionych Zakonowi przez swych poprzedników5.

Ogólnikowe zapewnienia dworu wiedeńskiego udzielane władzom zakonnym stały jednak w sprzeczności z rzeczywistymi zamiarami cesarza. Potrzebował on Hohenzollerna jako sojusznika i podczas prowadzonych z nim rokowań wyraził gotowość uznania go „królem w Prusach” (König in Preußen). Informowany na bieżąco o rozwoju wydarzeń Franciszek Ludwik von Pfalz-Neuburg podjął działania zmierzające do unicestwienia tych planów. Zwołał na 21 VI 1700 r. do Mergentheim

2 A. W a d d in g t o n, L'acquisition de la couronne royale de Prusse par les Hohenzollern, Paris 1888, zwł. s. 345-347.

3 B. D e m e 1, Franz Ludwig von Pfalz-Neuburg als Hoch- und Deutschmeister (16941732) und Bischof von Breslau (1683-1732), Jahrbuch der Schlesischen Friedrich-WilhelmsUniversität zu Breslau 36/37, 1995/1996, s. 93-150; t e n ż e, Franz Ludwig von Pfalz-Neuburg 1694-1732, w: Die Hochmeister des Deutschen Ordens 1190-1994, Marburg 1998 (Quellen und Studien zur Geschichte des Deutschen Ordens 40), s. 239-247.

${ }^{4}$ Kurbrandenburgs Staatsverträge von 1601 bis 1700, wyd. Th. von Moerner, Berlin 1867, s. 597-598, 798; J. Vot a, Der Untergang des Ordensstaates Preußen und die Entstehung der preußischen Königswürde, Mainz 1911, s. 538-540.

5 Remonstratio an die Römische Kaiserl. Majest. von des Herrn Hoch- und Teutschmeisters Hochfürst. Durchl., Mergentheim den 18 Oktober 1695 - Berlin-Dahlem, Geheimes Staatsarchiv Preußischer Kulturbesitz (dalej cyt.: GStAPK), I HA, rep. 132, nr 14, k. 479-481; F. Vo g e 1, Die preußische Königskrönung, s. 165; J. Vo i g t, Geschichte des Deutschen Ritter-Ordens in seinen zwölf Balleien in Deutschland, t. II, Berlin 1859, s. 447-450; D. J. We is s, Der Protest, s. 67. 
posiedzenie wielkiej kapituły Zakonu, które zostało poświęcone wyłącznie kwestii pruskiej ${ }^{6}$. Owocem obrad stał się kolejny protest krzyżacki przeciwko uzurpacjom Hohenzollernów brandenburskich, skierowany do Wiednia 7 IX 1700 r. $^{7}$ Wobec zignorowania go przez cesarza Leopolda I władze Zakonu odwołały się do Stolicy Apostolskiej. Poseł krzyżacki w Wiedniu, komtur Ellingen, awansowany wkrótce na komtura Ulm, Marsilius Heußlein von Eisenheim zwrócił się 11 XII 1700 r. do przebywającego na dworze cesarskim nuncjusza, aby wystąpił w imieniu nowego papieża Klemensa XI przeciwko brandenburskim planom koronacyjnym. Kiedy przedstawiciel papieski, arcybiskup Rimini Giovanni Antonio Davia, otrzymał stosowne instrukcje i 8 I 1701 r. okazał chęć poparcia krzyżackich postulatów - było już jednak za późno ${ }^{8}$. W dniu 15 I 1701 r. Hohenzollern ogłosił przez heroldów w Królewcu wywyższenie Księstwa Pruskiego do godności królewskiej, a trzy dni później odbyły się z wielkim przepychem właściwe ceremonie koronacyjne?

Pierwszy król w Prusach Fryderyk I (wcześniej elektor Fryderyk III) podjął natychmiast działania zmierzające do zneutralizowania akcji Zakonu. Jego sprzymierzeńcem na dworze wiedeńskim był wpływowy jezuita, kapelan i doradca cesarza Leopolda, baron Friedrich von Lüdinghausen (ojciec Wolff), który działał od dawna na rzecz zbliżenia między dworami Habsburgów i Hohenzollernów. Już 19 I 1701 r. ambasador Prus przy dworze wiedeńskim, baron Christian Friedrich von Bartholdi, doniósł swemu panu o planie wspomnianego jezuity. Doradzał on dworowi pruskiemu, aby poczynił Zakonowi darowiznę, na przykład scedował na rzecz Krzyżaków ekspektatywę Limburga. Zdaniem ojca Wolffa taki podarunek zamknąłby usta zakonnikom i zakończył tym samym dyskusję o prawach Hohenzollernów do Prus i tytułu królewskiego ${ }^{10}$. Pomysł został poważnie potraktowany przez dyplomację pruską. W dniu 25 I $1701 \mathrm{r}$. rozpoczęły się w Wiedniu długie negocjacje między Bartholdim a komturem Eisenheimem. Dyplomata krzyżacki przedstawił w trakcie rozmów prawa Zakonu do Prus, wynikające z nadań czynionych na rzecz wielkich mistrzów przez kolejnych cesarzy, w tym także przez obecnie panującego Leopolda I. Przypomniał również, że wkrótce po przejściu Albrechta Hohenzollerna na luteranizm i sekularyzacji Prus wszelkie prawa do tego kraju zostały przekazane przez cesarza Karola V zwierzchnikom niemieckiej gałęzi Zakonu. Bartholdi zbijał argumenty komtura, dowodząc, że elektorzy brandenburscy byli od 1657 r. suwerennymi książętami w Prusach. Podkreślał, że uzyskali suwerenność w Welawie od Korony Polskiej, a cesarz był nawet mediatorem i gwarantem tego traktatu ${ }^{11}$. Po ustaleniu listy

${ }^{6}$ F. Vo g e 1, Die preußische Königskrönung, s. 170; J. Vo i g t, Geschichte, t. II, s. 452; D. J. We is s, Der Protest, s. 68.

7 GStAPK, I HA, rep. 132, nr 14, k. 482-483; J. Vo ig t, Geschichte, t. II, s. 453-454; J. Vot a, Der Untergang, s. 566; D. J. We is s, Der Protest, s. 68.

${ }^{8}$ P. Hiltebrandt, Preußen und die römische Kurie, t. I, Berlin 1910, s. 89, nr 79, s. 92-93, nr 84; D. J. We is s, Der Protest, s. 72-73.

9 O. H in t z e, Die Hohenzollern und ihr Werk, Berlin 1916, s. 264; K. P i w a r s k i, Dzieje polityczne Prus Wschodnich (1621-1772), Gdynia 1938, s. 110-114; S. S a 1 m o n o w ic z, Prusy. Dzieje państwa i społeczeństwa, Poznań 1987, s. 130-132.

10 Bartholdi do Fryderyka I, Wiedeń 19 I 1701 (GStAPK, I HA, rep. 132, nr 7, k. 142-145).

11 Bartholdi do Fryderyka I, Wiedeń 26 I 1701 (GStAPK, I HA, rep. 132, nr 7, k. 313316); zob. A. Wa d d in g t o n, L'acquisition, s. 345. 
rozbieżności zajęto się sprawą ewentualnych rekompensat dla Zakonu. Eisenheim nie chciał zadowolić się podpowiadanym przez ojca Wolffa Limburgiem. Domagał się odstąpienia Krzyżakom przez Hohenzollernów tłustszego kąska - ekspektatywy na Fryzję Wschodnią ${ }^{12}$. Żądania te zostały uznane przez Fryderyka I za wygórowane. Monarcha dopuszczał jedynie możliwość rezygnacji z Limburga ${ }^{13}$.

Zakon nie ograniczał się do rozmów z dworem berlińskim i prób wytargowania rekompensaty. Ożywioną akcję agitacyjną w obronie praw krzyżackich do Prus rozwijał od stycznia 1701 r. poseł Zakonu akredytowany przy sejmie Rzeszy w Ratyzbonie, doktor nauk prawnych Georg Casimir von May ${ }^{14}$. Jego działania wspierał usilnie wielki mistrz Franciszek Ludwik von Pfalz-Neuburg, który 14 lutego wystosował do kolegium elektorskiego i do wszystkich uczestników sejmu oficjalną protestację przeciwko naruszeniu praw Zakonu przez Hohenzollerna ${ }^{15}$. Nie próżnowały także władze krzyżackie w Mergentheim - 11 II 1701 r. zwróciły się listownie o pomoc do katolickich elektorów Moguncji, Trewiru, Kolonii, Bawarii i Palatynatu Reńskiego ${ }^{16}$. Pozytywnie na ten apel odpowiedziało czterech z nich: arcybiskup moguncki Lotar Franciszek von Schönborn, arcybiskup trewirski Jan Hugo von Orsbeck, arcybiskup koloński Józef Klemens Wittelsbach i jego brat, elektor bawarski Maksymilian II Emanuel ${ }^{17}$.

Wielki mistrz Zakonu doczekał się również zdecydowanego wsparcia ze strony Stolicy Apostolskiej. Papież Klemens XI zwlekał przez kilka miesięcy z oficjalnym wystąpieniem, gdyż wobec konfliktu między królem Francji Ludwikiem XIV a dworem wiedeńskim o sukcesję hiszpańską starał się zachować zupełną neutralność i uniknąć podejrzeń, jakoby działał pod dyktando Wersalu. Dopiero gdy wojna stała się nieunikniona, papież uznał wyraźne zajęcie stanowiska za nieodzowne i wydał 16 IV $1701 \mathrm{r}$. brewe z protestem przeciwko bezprawnej koronacji margrabiego brandenburskiego. Protest oparto na przesłankach, że jedynie papieżowi przysługuje prawo szafarstwa godnością królewską oraz że papieże nigdy nie uznali wiarołomnego czynu Albrechta Hohenzollerna, sekularyzacji Prus, a więc w konsekwencji również prawa dynastii Hohenzollernów do tej ziemi. Tego samego dnia wysłano z Rzymu pisma do cesarza, królów Francji, Polski, Hiszpanii, Portugalii, doży Wenecji, katolickich kantonów Szwajcarii, duchownych elektorów Rzeszy Niemieckiej oraz elektora Bawarii z zaleceniem, aby nie uznawali koronacji pruskiej ${ }^{18}$. Władze

12 Bartholdi do Fryderyka I, Wiedeń 23 II 1701 (GStAPK, I HA, rep. 132, nr 10, k. 106108); zob. A. Wa d d in g t o n, L'acquisition, s. 346.

13 Fryderyk I do Bartholdiego, Królewiec 7 III 1701 (GStAPK, I HA, rep. 132, nr 10, k. 339-340).

${ }^{14}$ F. Vog e 1, Die preußische Königskrönung, s. 170-171.

15 K. W i e s e r, Nordosteuropa und der Deutsche Orden. Kurzregesten, t. II, Bad Godesberg 1972 (Quellen und Studien zur Geschichte des Deutschen Ordens 27), nr 4062.

16 Władze Zakonu do elektorów, Mergentheim 11 II 1701 (GStAPK, I HA, rep. 132, nr 10, k. 124-127).

17 E. I c h o n, Die Verhandlungen über die Anerkennung der preussischen Königswürde am Reichstage zu Regensburg (1701), Heidelberg 1907, s. 30-31; A. Wa d d in g to n, L'acquisition, s. 338; D. J. W e i s s, Der Protest, s. 71.

18 GStAPK, I HA, rep. 132, nr 14, k. 18, 20-26, 27-28; Wien, Haus-, Hof- und Staatsarchiv, VIII/1 Brandenburgica, nr 27, k. 79-80; K. P i w ars ki, Dzieje polityczne, s. 118-119; F. Vo g e 1, Die preußische Königskrönung, s. 172-173; J. Vo t a, Der Untergang, s. 588-589. 
Zakonu przyjęły wystąpienie Stolicy Apostolskiej z dużym zadowoleniem. Wielki mistrz osobiście podziękował 26 VI $1701 \mathrm{r}$. papieżowi za obronę praw krzyżackich ${ }^{19}$.

Pokrzepione na duchu władze Zakonu wystosowały na sejm Rzeszy w Ratyzbonie obszerny memoriał ze skargą na koronację królewiecką i uzurpację dokonaną przez elektora brandenburskiego Fryderyka $\mathrm{III}^{20}$. Datowane na 2 maja pismo, wydane pospiesznie drukiem, rozdano uczestnikom sejmu w dniu 6 VII 1701 r. Odnosiło się ono aż do czasów głębokiego średniowiecza. W obszernym wywodzie historycznym Krzyżacy przypomnieli, że już wielki mistrz Herman von Salza otrzymał od cesarza Fryderyka II w 1226 r. przywilej potwierdzający nie tylko darowiznę księcia mazowieckiego Konrada, ale także przekazujący Zakonowi pogańskie wówczas Prusy w bezpośrednie władanie. W 1283 r. rycerze zakonni dokonali ostatecznego podboju ziem pruskich i jaćwieskich. Zaprowadzili na ziemiach dawnych Prusów chrześcijaństwo, pobudowali twierdze, zamki, kościoły, klasztory, miasta i osady ${ }^{21}$. Okres pomyślności i pokoju zakończył się wraz z wyniesieniem na tron polski wielkiego księcia litewskiego Jagiełły. Rozpoczął on krwawe wojny z Zakonem, które kontynuował jego syn Kazimierz. Ten ostatni poparł rebelię wznieconą przez poddanych Zakonu i w wyniku wojny trzynastoletniej przyłączył do Korony Polskiej znaczną część ziem pruskich i narzucił polskie zwierzchnictwo, które Zakon próbował kwestionować, podobnie jak całą prawowitość traktatu toruńskiego z $1466 \mathrm{r}$. Wielki mistrz książę saski Fryderyk, dążąc do ułożenia na nowo relacji z Polską, doprowadził nawet przy pomocy cesarza i stanów Rzeszy do zwołania w tej sprawie zjazdu z przedstawicielami króla polskiego w Poznaniu w 1510 r. ${ }^{22}$ Następca Fryderyka saskiego, Albrecht von Brandenburg-Ansbach, siostrzeniec króla polskiego Zygmunta Starego, naśladował początkowo swych wielkich poprzedników i bronił mężnie Prus Zakonnych przed Polakami, kiedy jednak kończył się termin zawieszenia broni, zawartego (1521) przy pośrednictwie cesarza Karola V, zdecydował się na godny potępienia krok - przeszedł na luteranizm i 10 IV 1525 r. złożył w Krakowie hołd lenny królowi Zygmuntowi jako nowy świecki lennik Polski ${ }^{23}$.

Sekularyzacja Prus Krzyżackich, likwidacja duchownego władztwa Zakonu i przeobrażenie go w lenne księstwo rządzone przez reprezentantów ansbachskiej linii Hohenzollernów spotkały się z ostrą reakcją ze strony niemieckiej i inflanckiej gałęzi Zakonu. Autorzy memoriału skupili się - ze zrozumiałych względów - na działaniach podjętych przez Dytryka von Kleena, piastującego od 1515 r. godność mistrza niemieckiego (Deutschmeister). Rozwinął on szeroką akcję propagandową w Rzeszy Niemieckiej, tłumacząc książętom i szlachcie, że nieodpowiedzialny czyn Albrechta i szkodliwy traktat krakowski zagroził nie tylko dalszej egzystencji Zakonu,

19 K. W i e s e r, Nordosteuropa, t. II, nr 4102.

${ }^{20}$ Höchst abgenöthigtes Gravamen des Hohen Teutschen Ritter-Ordens uber den Seiner Churfürstl. Durchl. zu Brandenburg vor einigen Jahren anmaßlich zugelegten Titul eines Hertzogen, und nunmehr gar von aigener Macht vermeintlich-angenommene Königliche Würde von Preußen, 2 V 1701 - GStAPK, I HA, rep. 132, nr 14, k. 429-484. Druk ten był w literaturze (J. Vo t a, Der Untergang, s. 590; A. W a d d in g t o n, L'acquisition, s. 346-347; D. J. We is s, Der Protest, s. 70) wspominany tylko ogólnikowo, stąd też należy go szerzej omówić.

${ }^{21}$ GStAPK, I HA, rep. 132, nr 14, k. 433-434.

22 Tamże, k. 434-437.

23 Tamże, k. 437-440. 
ale również związkom łączącym Prusy z Rzeszą i cesarzem. W ślad za tym zwołał na 19 X 1525 r. do Spiry posiedzenie kapituły zakonnej, złożonej z przedstawicieli niemieckiej gałęzi Zakonu oraz baliwatów włoskich, w celu obmyślenia dalszych działań ratunkowych ${ }^{24}$.

Akcja Kleena zapobiegła jedynie rozpadowi ocalałej materialnej substancji zakonnej. Pomocy ze strony Habsburgów doczekał się bowiem dopiero jego następca Walter von Cronberg, następca Kleena, który ustąpił z urzędu z powodu podeszłego wieku w grudniu 1526 r. Urzędujący w nowej siedzibie mistrzów niemieckich we frankońskim zamku w Mergentheim nad Tauberą Cronberg został uznany głową Zakonu, bez uciekania się - ze względu na Prusy - do wyboru nowego wielkiego mistrza. W dniu 6 XII 1527 r. w kastylijskim Burgos cesarz Karol V wystawił bowiem przywilej (Regal-Brief), mianujący mistrza niemieckiego Waltera von Cronberga administratorem urzędu wielkiego mistrza w Prusach. Niecałe trzy lata później doszło do dalszego wzmocnienia pozycji Zakonu. Cesarz Karol V uznał traktat krakowski za nieważny i 26 VII 1530 r. wśród uroczystej oprawy nadał Cronbergowi na sejmie Rzeszy w Augsburgu Prusy Krzyżackie jako księciu Rzeszy ${ }^{25}$.

Ogłoszony banitą Rzeszy książę Albrecht Hohenzollern utrzymał się jednak przy władzy w Prusach, choć Habsburgowie podtrzymywali konsekwentnie pretensje Zakonu do ziem pruskich. Po śmierci Cronberga w 1543 r. Zakon zażądał nadania Prus w lenno nowemu mistrzowi, którym został Wolfgang Schutzbar zwany Milchling. Cesarz Karol V uczynił temu zadość i 5 V 1544 r. przekazał mu uroczyście w Spirze regalia wielkiego mistrza w Prusach. Podobnych dowodów poparcia ze strony Habsburgów doczekał się następca zmarłego 11 XII 1566 r. Schutzbara - Jerzy Hund von Wenkheim, który 9 V 1566 r. otrzymał od cesarza Maksymiliana II na sejmie Rzeszy w Augsburgu godność administratora Prus oraz regalia wielkiego mistrza. W tym stanie rzeczy - argumentowali autorzy memoriału - władze Zakonu miały wszelkie prawa do tego, aby podważać legalność panowania linii ansbachskiej Hohenzollernów i protestować przeciwko dopuszczeniu do lenna pruskiego przez króla polskiego Zygmunta Augusta ich dalszych krewnych, elektora brandenburskiego Joachima II oraz jego dwóch synów. Podkreślali przy tym, że śmierć Albrechta Hohenzollerna w 1568 r. i decyzje króla polskiego nie dokonały wyłomu w przyjętym przed laty sposobie postępowania Habsburgów, najznaczniejszych i najbardziej wpływowych władców chrześcijańskiej Europy. Stąd też następca zmarłego 17 VI 1572 r. Wenkheima, Henryk von Bobenhausen, uzyskał niezwłocznie od cesarza Maksymiliana II nadanie lenna pruskiego (17 IX 1572 r. w Preszburgu) ${ }^{26}$.

Podobnymi łaskami dworu cesarskiego cieszyli się następcy Bobenhausena, który zrezygnował z urzędu w 1590 r. Hofburg konsekwentnie wspierał pretensje do ziem pruskich kolejnych zwierzchników Zakonu, określanych, począwszy od Cronberga, mianem ,wielkich i niemieckich mistrzów” (Hoch- und Deutschmeister). Nie zmienił tego stanu rzeczy nawet traktat welawski z 1657 r., zawarty w obecności

24 Tamże, k. 440-441.

25 Tamże, k. 441-442, 466-472.

26 Tamże, k. 442-443 (autorzy memoriału nie podali dokładnej daty ani miejsca tego wydarzenia). Por. J. Vo i g t, Geschichte, t. II, s. 179-184, 208-212, 229-233; J. Vo t a, Der Untergang, s. 397-398, 418-420, 437-438, 453-461. 
przedstawiciela Leopolda I Habsburga. Autorzy memoriału zasygnalizowali wyraźnie, że w momencie uzyskania przez elektora brandenburskiego Fryderyka Wilhelma suwerenności w Księstwie Pruskim Leopold nie był cesarzem, lecz tylko królem $\mathrm{Czech}^{27}$. O postępach Hohenzollernów brandenburskich w Księstwie Pruskim decydowała Korona Polska, a nie dwór wiedeński. To władcy Polski przekazali elektorom brandenburskim rządy w lennie pruskim po wymarciu ansbachskiej linii Hohenzollernów, a następnie uczynili ich władcami suwerennymi w Prusach. Prezentację idealnej harmonii zachodzącej między Cesarstwem a Zakonem zakłócał jedynie końcowy fragment zbioru dokumentów dołączony do memoriału. Po przywilejach cesarzy Fryderyka II z 1226, Henryka VII z 1311, Ludwika IV z 1338, Karola IV z 1354 i Karola V z 1527 r. znalazły się w nim protestacje krzyżackie przeciwko uzurpacjom Hohenzollernów, kierowane na dwór habsburski w latach 1695, 1697 i 1700²8.

Omówienie memoriału należy uzupełnić uwagami na temat polityki Habsburgów względem Zakonu. Cesarze, podobnie jak władcy Polski, musieli liczyć się coraz bardziej ze wzrostem politycznego znaczenia brandenburskiej linii Hohenzollernów. Z kolei Krzyżacy upatrywali swych strategicznych opiekunów w katolickich Habsburgach, którzy już u schyłku XVI w. zaczęli narzucać reprezentantów swojej dynastii na stanowisko zwierzchników Zakonu. Pierwszym Habsburgiem na urzędzie wielkiego i niemieckiego mistrza był w latach 1590-1618 arcyksiążę austriacki Maksymilian, piastujący wcześniej od 1585 r. stanowisko koadiutora wielkiego mistrza Bobenhausena. Ten sam Maksymilian w 1587 r. pretendował do tronu polskiego jako konkurent Stefana Batorego. Zakon finansował wtedy nawet jego wyprawę do Polski, spodziewając się poparcia habsburskiego w kwestii Prus i Inflant ${ }^{29}$. Wobec klęski arcyksięcia w Polsce jedynym sukcesem dyplomatycznym odniesionym przez Zakon podczas jego rządów był mandat wystawiony przez kancelarię cesarza Macieja 23 VIII 1613 r. w Ratyzbonie, potwierdzający posiadanie lenna pruskiego oraz administrację urzędu wielkiego mistrza w Prusach ${ }^{30}$.

Niewiele wskórał także inny Habsburg, syn cesarza Ferdynanda II, arcyksiążę Leopold Wilhelm, wielki i niemiecki mistrz w latach 1641-1662. Projekt z 1656 r. dotyczący osadzenia go w Prusach Książęcych i ukarania w ten sposób za felonię oraz przejście do obozu szwedzkiego elektora brandenburskiego Fryderyka Wilhelma spodobał się opozycji stanowej w Księstwie Pruskim oraz niektórym Polakom. Hofburg jednak zajął w tej sprawie niezdecydowane stanowisko ${ }^{31}$. Cesarze musieli coraz częściej zabiegać o dobre relacje z elektorami brandenburskimi, spychając na plan dalszy interesy Zakonu, choć nadal nadawali kolejnym mistrzom krzyżackim przywileje i regalia - w latach 1622, 1625, 1628, 1637, 1651, 1661, 1665 i $1696^{32}$. Wszystkie te inwestytury pozwalały jednak tylko na podtrzymywanie papierowych roszczeń Zakonu do ziem pruskich.

27 GStAPK, I HA, rep. 132, nr 14, k. 444.

28 Tamże, k. 446-483.

29 J. Vo i g t, Geschichte, t. II, s. 260-271; J. Vot a, Der Untergang, s. 467-469.

30 J. Vo ig t, Geschichte, t. II, s. 294-296.

31 A. K a m i eń s k i, Stany Prus Książęcych wobec rządów brandenburskich w drugiej połowie XVII wieku, Olsztyn 1995, s. 76.

32 J. Vo i g t, Geschichte, t. II, s. 296, przyp. 1. 
W dniu 16 XI 1700 r. doszło do zawarcia tzw. traktatu koronacyjnego, w którym cesarz Leopold I w zamian za pomoc militarną w sile 8000 żołnierzy oraz obietnicę wsparcia w przyszłej elekcji i współdziałania politycznego przyrzekł elektorowi brandenburskiemu Fryderykowi III uznanie jego tytułu królewskiego natychmiast po koronacji3 ${ }^{33}$. Odnowienie przez Hofburg sojuszu z Brandenburgią z 1686 r. i tak daleko idące ustępstwa na rzecz Hohenzollernów postawiły ówczesnego zwierzchnika Zakonu na straconej pozycji. Akcja protestacyjna podjęta przez władze krzyżackie na sejmie Rzeszy, na dworach katolickich władców Rzeszy Niemieckiej i w Stolicy Apostolskiej nie wywarła na Leopoldzie I odpowiedniego wrażenia. Szykujący się do wojny o sukcesję hiszpańską i potrzebujący brandenburskiego mięsa armatniego Habsburg pozostawał długo głuchy na skargi krzyżackie. Dopiero 27 VIII $1701 \mathrm{r}$. udzielił Zakonowi dość ogólnikowej odpowiedzi, w której potwierdził zachowanie przez Krzyżaków dotychczasowych praw i prerogatyw oraz zagwarantował w imieniu swoim i swoich następców, że katoliccy cesarze z dynastii Habsburgów nie będą nigdy wahać się z nadawaniem Zakonowi zwyczajowej inwestytury ${ }^{34}$. Zapewnienia te miały iluzoryczną wartość. Już bowiem 22 II $1701 \mathrm{r}$. Leopold I, odpowiadając na hohenzollernowską notyfikację, zaakceptował tytuł „króla w Prusach” przybrany przez elektora brandenburskiego ${ }^{35}$. Trudno przypuszczać, aby decyzja cesarska nie była znana Krzyżakom. Raczej nie chcieli o niej wiedzieć. Świadczy o tym najlepiej list władz zakonnych z 8 III $1701 \mathrm{r}$. z dramatycznym apelem skierowanym do Leopolda I, aby ten zapobiegł uznaniu tytułu królewskiego Hohenzollerna w Prusach ${ }^{36}$.

Franciszek Ludwik von Pfalz-Neuburg nie dawał jednak wciąż za wygraną. W piśmie wystosowanym 28 X 1701 r. do sejmujących w Ratyzbonie stanów Rzeszy domagał się ponownie od elektorów i książąt, aby ci nie uznawali przybranego przez margrabiego brandenburskiego tytułu królewskiego, gdyż godzi on w ustrój Rzeszy i prawa Zakonu ${ }^{37}$. Szeregi partii sympatyzującej z poglądami krzyżackimi topniały jednak systematycznie. $\mathrm{W}$ ślad za terytorialnymi władcami protestanckimi z Hesji, Brunszwiku, Hanoweru, Wirtembergii, Saksonii, Meklemburgii i Anhaltu zaczęli podążać katolicy. Pod naciskiem Hofburga do końca listopada $1701 \mathrm{r}$. tytuł królewski Hohenzollernów brandenburskich uznało co najmniej siedmiu książąt duchownych: biskup Osnabrück Karol Józef Lotaryński (7 III 1701) $)^{38}$, biskup Hildesheim Jobst Edmund von Brabeck (2 IV 1701) (39 $^{39}$, biskup Augsburga Aleksander Zygmunt Wittelsbach (24 IV 1701) ${ }^{40}$, biskup Konstancji Markward Rudolf von Rodt zu Bußmannshausen (15 V 1701 r. $)^{41}$, biskup Eichstätt Jan Marcin von Eyb

33 Kurbrandenburgs Staatsverträge, s. 673-678, 810-823.

${ }^{34}$ GStAPK, I HA, rep. 132, nr 17, k. 99a, 349. Por. J. Vo i g t, Geschichte, t. II, s. $455-$ 456; J. Vo t a, Der Untergang s. 592; A. W a d d i n g t o n, L'acquisition, s. 347; D. J. We is s, Der Protest, s. 75.

35 GStAPK, I HA, rep. 132, nr 10, k. 71-72; J. Vota, Der Untergang, s. 586;

A. Wa d d in g t o n, L'acquisition, s. 309.

${ }^{36} \mathrm{~K}$. W i e s e r, Nordosteuropa, t. I, nr 4083.

37 Tamże, nr 4111; D. J. We i s s, Der Protest, s. 75.

38 GStAPK, I HA, rep. 132, nr 15, k. 387.

39 Tamże, nr 12, k. 15-16.

40 Tamże, k. 444.

${ }^{41}$ Tamże, nr 13, k. 304. 
(16 VI 1701) ${ }^{42}$, biskup Münster Fryderyk Krystian von Plettenberg-Lenhausen (7 VIII $1701)^{43}$ i biskup Pasawy, kardynał Jan Filip von Lemberg (28 XI 1701) ${ }^{44}$, a także książę-opat Fuldy Adalbert von Schleifras (2 VIII 1701 r. $)^{45}$. Po stronie Hohenzollerna opowiedział się również starszy brat zwierzchnika Zakonu, elektor Palatynatu Reńskiego Jan Wilhelm, akceptując pruski tytuł królewski 23 III 1701 r. ${ }^{46}$ Angażował się on później w akcję mediacyjną między dworem berlińskim i Krzyżakami, zapewniając wielkiego mistrza w piśmie z 21 VII 1701 r. o możliwości uzyskania od Hohenzollerna „adekwatnej rekompensaty” za wycofanie się Zakonu z akcji protestacyjnej i rezygnację z pretensji do brandenburskiej części Prus ${ }^{47}$.

Franciszek Ludwik von Pfalz-Neuburg mógł jednak wciąż liczyć na poparcie kilkunastu władców terytorialnych, m.in. czterech elektorów katolickich z Bawarii, Kolonii, Moguncji i Trewiru, arcybiskupa Salzburga oraz biskupa Würzburga. Jeszcze w połowie stycznia $1702 \mathrm{r}$. zagrzewał tego ostatniego do dalszej obrony krzyżackich praw ${ }^{48}$. Biskup Würzburga Jan Filip von Greiffenclau zu Vollraths podją już jednak decyzję o akceptacji tytułu królewskiego Hohenzollernów i wysłał w tej sprawie poselstwo do Berlina, na którego czele stanął tajny radca, baron Christian Ernst Fuchs von Bimbach. Przekazał on 4 II 1702 r. królowi Prus list gratulacyjny od swego pana, antydatowany na 12 II $1701 \mathrm{r}^{49}$ Wielkiego mistrza spotkał $4 \mathrm{X}$ $1703 \mathrm{r}$. kolejny zawód, tym razem ze strony arcybiskupa trewirskiego Jana Hugona von Orsbecka, który przyłączył się do grona osób akceptujących godność królewską Hohenzollernów, choć jeszcze 27 XI 1701 r. zapewniał Zakon o swym niezłomnym stanowisku w kwestii pruskiej ${ }^{50}$. Niemal równocześnie z Orsbeckiem, gdyż 30 IX 1703 r., na normalizację relacji z Hohenzollernem, bez oglądania się na pretensje krzyżackie, zdecydował się arcybiskup moguncki Lotar Franciszek von Schönborn ${ }^{51}$.

Pierwszy król w Prusach, Fryderyk I, zachęcony pomyślnym dla siebie rozwojem wydarzeń, zaostrzał systematycznie swoje relacje z Zakonem. Nie czekał aż koronacja królewiecka spotka się z uznaniem wszystkich władców terytorialnych Rzeszy Niemieckiej, Państwa Kościelnego oraz innych państw europejskich. Już 17 XII 1701 r. polecił swemu ambasadorowi w Wiedniu, Christianowi Friedrichowi von Bartholdiemu, aby zaprzestał rozmów z delegatem wielkiego mistrza na

42 Tamże, nr 14, k. 168.

43 Tamże, nr 15, k. 303.

44 Tamże, nr 17, k. 271.

45 Tamże, nr 15, k. 287.

46 Preussens Staatsverträge aus der Regierungszeit König Friedrichs I., wyd. V. Loewe, Leipzig 1923, s. 1-3; E. I c h o n, Die Verhandlungen, s. 37; A. W a d d i n g t o n, L'acquisition, s. $340-341$.

${ }^{47} \mathrm{~K}$. W i e s e r, Nordosteuropa, t. II, nr 4105. Por. U. A r n o ld, Mergentheim und Königsberg/Berlin - die Rekuperationsbemühungen des Deutschen Ordens auf Preußen, Württembergisch Franken. Jahrbuch des Historischen Vereins für Württembergisch Franken 60, 1976, s. 40; D. J. We i s s, Der Protest, s. 72.

48 A. Wa d d ing t o n, L'acquisition, s. 344.

49 GStAPK, I HA, rep. 132, nr 18, k. 49-50 oraz 51 (odpowiedź Fryderyka, Kölln 7 II 1702).

50 GStAPK Berlin-Dahlem, I HA, rep. 132, nr 19, k. 325-327; F. Vogel, Die preußische Königskrönung, s. 174.

51 GStAPK Berlin-Dahlem, I HA, rep. 132, nr 19, k. 321-322. 
temat ekspektatywy Limburga, który stanowić miał odszkodowanie dla Zakonu ${ }^{52}$. Równocześnie z zabiegami dyplomatycznymi rozpętała się walka publicystyczna. Hohenzollern zaangażował $\mathrm{w}$ nią swoich najlepszych prawników $\mathrm{z}$ uniwersytetu w Halle - Christiana Thomasiusa i Johanna Petera Ludewiga. Zajęto się badaniem tytułów prawnych Krzyżaków do Prus oraz praw zwierzchnich Polski do tych ziem po zajęciu ich przez Zakon. W zwalczaniu uprawnień krzyżackich dwór berliński stanął na podobnym stanowisku, jakie zajmowała Polska podczas sporów w średniowieczu. Najdobitniej na skargi krzyżackie odpowiedział Ludewig w pracy „Vertheidigtes Preußen wider den vermeinten und widerrechtlichen Anspruch des Teutschen Ritterordens". W piśmie tym ogłoszonym drukiem w 1703 r., zaopatrzonym celowo w sfingowane miejsce wydania (Mergentheim, choć było to prawdopodobnie Halle), dowodził, że Zakon Niemiecki i cesarz nie mają żadnych praw do posiadania Prus i ziemi chełmińskiej, ponieważ prawo zwierzchnie do tych ziem znajdowało się w ręku księcia mazowieckiego Konrada. Rzecznik interesów Hohenzollerna wskazywał na krzywdy wyrządzone Polsce przez Krzyżaków. Utrzymywał, że Zakon podbił Prusy „pod pozorem czci Bożej”, pozwalając sobie na złamanie wszelkich zasad wierności w stosunku do władców polskich. Spotkała go za to zasłużona kara. Przekonany o własnej bezkarności zaczął bowiem żyć w rozpuście i tyranizować swoich poddanych, aż w końcu w $1525 \mathrm{r}$. utracił na zawsze prawo do sprawowania w Prusach jakiejkolwiek władzy ${ }^{53}$.

Wobec tak ogromnej różnicy poglądów obie strony sporu pozostały przy swoim zdaniu. Hohenzollernowie brandenburscy zajęli się dalszym umacnianiem swej pozycji wśród europejskich domów panujących, natomiast władze Zakonu kontestowały przybrany przez nich tytuł królewski. Wykazały się przy tym większą konsekwencją niż Stolica Apostolska, która uznała koronację królewiecką w 1788 r. ${ }^{54}$ Zakon nie uczynił tego nigdy. Żadna z protestacji krzyżackich nie uzyskała jednak tak dużego rozgłosu, jak ta z 1701 r. Zakon, który nie odgrywał już od dawna znaczącej roli politycznej, przebił się bowiem wówczas ze skargami na forum ogólnoniemieckie i europejskie. Zadecydowało o tym kilka przyczyn. Nie ulega wątpliwości, że twierdzenia o nielegalności tytułu książęcego Hohenzollernów, jak i świeżego królewskiego były na rękę tym wszystkim siłom, które dążyły do rozbicia kształtującej się koalicji cesarza z obozem państw protestanckich. Do tego dochodziła jeszcze niechęć części władców terytorialnych Rzeszy do Hohenzollernów oraz obawy przed nadmiernym wzrostem potęgi Brandenburgii-Prus. Większość opozycji antyhohenzollernowskiej stanowili katolicy postawieni przed trudnym wyborem między zacieśniającym swe związki z protestantami Hofburgiem a Wersalem. Ich szybkie opowiedzenie się, choć nie

52 Fryderyk I do Ch. F. von Bartholdiego, Kölln nad Sprewą 17 XII 1701, GStAPK BerlinDahlem, I HA, rep. 132, nr 17, k. 351-352.

${ }^{53}$ GStAPK, I HA, rep. 132, nr 14, k. 218-219; U. A r n o ld, Mergentheim, s. 41; M. B is k u p, G. L a b u d a, Dzieje Zakonu Krzyżackiego w Prusach. Gospodarka - społeczeństwo - państwo - ideologia, Gdańsk 1986, s. 15; Th. S c h i e d e r, Die preußische Königskrönung von 1701 und die politische Ideengeschichte, Altpreußische Forschungen 12, 1935, s. 70-71; J. Vot a, Der Untergang, s. 591; D. J. W e is s, Der Protest, s. 75-76.

${ }_{54}$ F. Vo g e 1, Die preußische Königskrönung, s. 179; A. W a d d i n g t o n, L'acquisition, s. $357-358$. 
wszystkich, po stronie cesarza, a co za tym idzie - także Hohenzollerna, przesądziło o niepowodzeniu całej akcji Krzyżaków i zbyciu ich pretensji bez jakiegokolwiek odszkodowania. Instytucje zakonne były związane z dynastią habsburską i wszelkie posunięcia polityczne zmierzające do podtrzymania planów rekuperacji Prus były uzależnione od poparcia Hofburga, który nie przykładał do nich od dawna większej wagi. W sporze krzyżacko-hohenzollernowskim nie odegrały większego znaczenia więzy krwi łączące ówczesnego wielkiego mistrza Franciszka Ludwika von Pfalz-Neuburg z wpływowymi książętami Rzeszy Niemieckiej. Jego dwaj starsi bracia, elektor Palatynatu Jan Wilhelm i biskup Augsburga Aleksander Zygmunt, wycofali się z popierania papierowych przedsięwzięć Zakonu jeszcze przed złożeniem przez Krzyżaków na sejmie w Ratyzbonie słynnego memoriału. Inaczej zachowali się dalsi krewni - Wittelsbachowie z linii bawarskiej: arcybiskup koloński Józef Klemens i elektor bawarski Maksymilian II Emanuel. Uznali oni tytuł królewski Hohenzollernów dopiero kilkanaście lat później, w $1714 \mathrm{r} .{ }^{55}$ Władcy ci nie kierowali się jednak dobrem Zakonu, lecz przede wszystkim własnym interesem dynastycznym. Szansę na realizację swoich planów widzieli w sojuszu z Francją, co postawiło ich automatycznie po stronie wrogów cesarza i świeżo upieczonego króla w Prusach.

\section{BIBLIOGRAFIA}

Arnold U., Mergentheim und Königsberg/Berlin - die Rekuperationsbemühungen des Deutschen Ordens auf Preußen, Württembergisch Franken, Jahrbuch des Historischen Vereins für Württembergisch Franken 60, 1976.

Baumgart P., Kurfürst Max Emanuel von Bayern und die preußische Rangerhöhung, w: Die preußische Rangerhöhung und Königskrönung 1701 in deutscher und europäischer Sicht, Frankfurt am Main 2002.

Biskup M., Labuda G., Dzieje Zakonu Krzyżackiego w Prusach. Gospodarka - społeczeństwo - państwo - ideologia, Gdańsk 1986.

Demel B., Franz Ludwig von Pfalz-Neuburg 1694-1732, w: Die Hochmeister des Deutschen Ordens 1190-1994, Marburg 1998 (Quellen und Studien zur Geschichte des Deutschen Ordens 40).

Demel B., Franz Ludwig von Pfalz-Neuburg als Hoch- und Deutschmeister (1694-1732) und Bischof von Breslau (1683-1732), Jahrbuch der Schlesischen Friedrich-Wilhelms-Universität zu Breslau 36/37, 1995/1996.

Hiltebrandt P., Preußen und die römische Kurie, t. I, Berlin 1910.

Hintze O., Die Hohenzollern und ihr Werk, Berlin 1916.

Ichon E., Die Verhandlungen über die Anerkennung der preussischen Königswürde am Reichstage zu Regensburg (1701), Heidelberg 1907.

Kamieński A., Stany Prus Książęcych wobec rządów brandenburskich w drugiej połowie XVII wieku, Olsztyn 1995.

Piwarski K., Dzieje polityczne Prus Wschodnich (1621-1772), Gdynia 1938.

Salmonowicz S., Prusy. Dzieje państwa i społeczeństwa, Poznań 1987.

Schieder Th., Die preußische Königskrönung von 1701 und die politische Ideengeschichte, Altpreußische Forschungen 12, 1935.

55 P. B a u m g a r t, Kurfürst Max Emanuel von Bayern und die preußische Rangerhöhung, w: Die preußische Rangerhöhung und Königskrönung 1701 in deutscher und europäischer Sicht, Frankfurt am Main 2002, s. 127; E. I c h o n, Die Verhandlungen, s. 36; A. W a d d in g t o n, L'acquisition, s. 338-340. 
Vogel F., Die preußische Königskrönung und der Deutsche Orden (1695-1701), w: Die landesgeschichtliche Bedeutung der Königskrönung von 1701. Marburg 2004 (Tagungsberichte der Historischen Kommission für Ost- und Westpreussische Landesforschung 18).

Voigt J., Geschichte des Deutschen Ritter-Ordens in seinen zwölf Balleien in Deutschland, t. II, Berlin 1859.

Vota J., Der Untergang des Ordensstaates Preußen und die Entstehung der preußischen Königswürde, Mainz 1911.

Waddington A., L'acquisition de la couronne royale de Prusse par les Hohenzollern, Paris 1888.

Weiss D. J., Der Protest des Deutschen Ordens gegen die preußische Königskrönung 1701, w: Die preußische Rangerhöhung und Königskrönung 1701 in deutscher und europäischer Sicht, Frankfurt am Main 2002.

Wieser K., Nordosteuropa und der Deutsche Orden. Kurzregesten, t. II, Bad Godesberg 1972

(Quellen und Studien zur Geschichte des Deutschen Ordens 27).

\section{The Teutonic Order against the coronation of Frederic III, Elector of Brandenburg, as the king in Prussia}

Summary

The coronation of Frederic III, Elector of Brandenburg, as the king in Prussia on 15 January 1701 met with a fierce protest of the Teutonic Order. The information about it quickly spread all over Germany and Europe. It turned out that raising the rule of the Hohenzollerns from Brandenburg to the rank of a kingdom was against the wishes of other political powers, much more important than the Teutonic Knights, such as France, Spain, Venice, the Polish-Lithuanian state, the Holy See, and most of the Catholic territorial entities of the German Reich. In such conditions a chance appeared for the Teutonic Order to use the auspicious situation and negotiate from Hohenzollern a rich compensation. Negotiations were carried out with the envoy of the Berlin court in Viena, but were terminated in December 1701 on the initiative of the newly crowned king in Prussia. The failure of the attempts of the Teutonic Knights was caused by the dynamically changing international situation. The growing conflict between Habsburgs and Bourbons regarding the Spanish succession forced Emperor Leopold I and the states related to him, as well as the territorial entities of the German Reich, to take Hohenzollern's side. 